\title{
HUBUNGAN ANTARA PERILAKU ASERTIF DENGAN PERENCANAAN KARIR PADA SISWA MTs. NW TANAK MAIK MASBAGIK KABUPATEN LOMBOK TIMUR
}

\author{
Sudirman $^{1}$, Ani Endriani ${ }^{2}$ \\ Program Studi Bimbingan Konseling, FIPP UNDIKMA \\ E-mail: aniendriani20@gmail.com
}

\begin{abstract}
Abstrak: Perilaku asertif merupakan tingkah laku yang bersifat terbuka, bersikaf jujur, bertanggung jawab menghargai pendapat orang lain dan bisa memahami lingkungan sekitar yang bisa mengekspresikan dalam diri individu dan lingkungan sosial memudahkan untuk menentukan perencanaan. Perencanaan karir merupakan suatu langkah yang dilakukan oleh siswa dalam menentukan arah pilihan karir sesuai dengan harapan agar siswa tidak salah dalam mengambil keputusan karir seperti kelanjutan studi, cita-cita serta pekerjaan yang diinginkan. Berdasarkan latar belakang diatas, maka dapat dirumuskan masalah sebagai berikut apakah ada hubungan antara perilaku asertif dengan perencanaan karir pada siswa MTs. NW Tanak Maik Masbagik Kabupaten Lombok Timur. Sedangkan tujuan dalam penelitian ini adalah untuk mengetahui hubungan antara perilaku asertif dengan perencanaan karir pada siswa MTs. NW Tanak Maik Masbagik Kabupaten Lombok Timur. Metode yang digunakan dalam penelitian ini adalah angket sebagai metode pokok sedangkan metode obserpasi, wawancara, dan dokumentasi sebagai metode pelengkap.Adapun jumlah sampel yang diambil dalam penelitian ini adalah seluruh siswa yang berumlah81 orang siswa. Analisis data dengan menggunakan korelasi product moment diperoleh nilai rhitung lebih besar dari rtabel pada taraf signifikansi $5 \%$ dengan $\mathrm{N}=81$ orang, nilai rhitung $>$ rtabel atau 0,742>0,213 yang berarti penelitian ini dinyatakan signifikan artinya hipotesis nihil (Ho) yang berbunyi "tidak ada hubungan antara perilaku asertif dengan perencanaan karir pada siswa MTs. NW Tanak Maik Masbagik Kabupaten Lombok Timur" di tolak, sedangkan hiptesis alternatif (Ha) yang berbunyi "ada hubungan antara perilaku asertif dengan perencanaan karir pada siswa MTs. NW Tanak Maik Masbagik Kabupaten Lombok Timur" diterima.
\end{abstract}

Kata Kunci :Perilaku Asertif, Perencanaan Karir

\section{PENDAHULUAN}

Era globalisasi ini, manusia sedang memasuki suatu abad baru yang banyak menimbulkan perubahan dan kemajuan, sekaligus menjadi tantangan.Tantangan akibat perubahan dan kemajuan yang cepat, terjadi baik pada aspek sosial, budaya, dan teknologi.Permasalahan-permasalahan yang dihadapi akibat perubahan tersebut semakin konflik baik masalah pribadi, sosial, ekonomi, budaya dan lain-lain.Untuk menghadapi tantangan ini diperlukan kesiapan individu secara fisik dan psikis, agar lebih mampu mengatasi berbagai masalah dalam mencapai kesuksesan.Setiap individu dalam 
melaksanakan hubungan atau berinteraksi sosial pasti membutuhkan suatu kemampuan berkomunikasi secara terbuka dan jujur pada individu yang memiliki tingkah laku asertif. Perilaku asertifadalah: antar perorangan (interpersonal) yang melibatkan aspek kejujuran dan keterbukaan pikiran dan perasaan (Gunarsa, 2009: 215).Pengertian atau makna perilaku asertif menurut Rini, 2001 dalam Khan(2012 : 145) suatu kemampuan untuk mengkomunikasikan apa yang diinginkan, dirasakan, dan dipikirkan kepada orang lain namun tetap menjaga dan menghargai hak-hak serta perasaan pihak lain.

Berdasarkan pendapat di atas, peneliti dapat menyimpulkan bahwa perilaku asertif adalah : perilaku yang bersikap jujur, bersifat terbuka, menghargai pendapat orang lain dan bisa memahami lingkungan sekitar. Adapun indikator dari perilaku asertif antara lain : (1) bersifat jujur, (2) bersifat terbuka, dan (3) bertanggung jawab. Apabila terwujudnya perilaku asertif maka siswa dapat melihat perencanaan karir kedepannya.

Perencanaan karir merupakan proses pencapaian tujuan karir individu, yang ditandai dengan adanya tujuan yang jelas setelah menyelesaikan pendidikan, cita-cita yang jelas terhadap pekerjaan, dorongan untuk maju dalam bidang pendidikan dan pekerjaan yang di cita-citakan, persepsi yang realistis terhadap diri dan lingkungan, kemampuan mengelompokkan pekerjaan yang diminati, memberikan penghargaan yang positif terhadap pekerjaan dan nilai-nilai, kemandirian dalam proses mengambil keputusan, kematanan dalam hal mengambil keputusan, dan menunjukkan cara-cara realistis dalam mencapai cita-cita pekerjaan. Super dalam Adiputra(2015 : 47).Sedangkan Frank Parson dalam Winkel \& Hastuti (2010:408) merumuskan perencanaan karir yaitu suatu cara untuk membantu siswa dalam memilih suatu bidang karir yang sesuai dengan potensi mereka, sehingga dapat cukup berhasil di bidang pekerjaan. Perencanaan karir perlu disiapkan sebelum siswa terjun secara langsung dalam dunia karir. Perencanaan karir didasarkan atas potensi yang dimiliki siswa sehingga tidak ada pertentangan antara karir yang dipilih dengan potensi yang ada pada diri siswa

Beberapa pendapat di atas, yang dimaksud dengan perencanaan karir adalah : suatu langkah yang dilakukan oleh siswa dalam menentukan arah pilihan karir sesuai dengan harapan agar siswa tidak salah dalam mengambil keputusan karir seperti kelanjutan studi, cita-cita serta pekerjaan yang diinginkan. Adapun indikator perencanaan karir 
antara lain : (1) mencari informasi tentang karir, (2) mengidenfikasi dan mengambil langkah untuk mencapai tujuan karir, (3) fokus pada tujuan yang ditetapkan.

\section{KAJIAN PUSTAKA}

\section{Konsep Perilaku Asertif}

Perilaku asertif

adalah : perilaku

interpersonal

individu

yang

berupa pernyataan mengenai apa yang dirasakan oleh individu tersebut, yang bersifat jujur dan relatif langsung (Rimm \& Master dalam Marini, 2005). Pengertian atau makna perilaku asertif menurut Rini, 2001 dalam Khan(2012 : 145) suatu kemampuan untuk mengkomunikasikan apa yang diinginkan, dirasakan,dan dipikirkan kepada orang lain namun tetap menjaga dan menghargai hak-hakserta perasaan pihak lain.

Dari pendapat di atas, peneliti dapat menyimpulkan bahwa prilaku asertif adalah :perilaku untuk mengemukakan pikiran, perasaan serta mengekspresikan emosi dan ide secara layak, bersikap jujur dan terbuka kepada orang lain dengan cara yang sesuai tanpa merugikan diri sendiri dan orang lain.

\section{Ciri-ciri perilaku asertif}

Individu yang memiliki perilaku asertif mempunyai karakteristik tersendiri seperti, tegas dalam mengambil keputusan, berjiwa kepemimpinan, jelas dalam mengungkapkan kata-kata, jujur dan terbuka dalam hal positif, ciri-ciri individu yang asertif adalah : 1)bicara jujur,2) memperlukan orang lain dengan hormat, begitu pula dengan sebaliknya, 3) menampilkan diri sendiri dan menyayangi orang lain, 4) memiliki hubungan yang baik dan efektif dengan orang lain dan, 5) tenang dalam kesehariandan memperlihatkan selera humor dalam menghadapi situasi yang sulit falmer dan frokner(dalam http:zhalabe.blogspot.com).

Adapun ciri-ciri di atas merupakan perilaku yang dimiliki oleh individu yang bertingkah laku asertif, ciri-ciri tersebut dapat membedakan satu dengan yang lainnya, karena individu yang memiliki tingkah laku asertif bisa berinteraksi dan bekomunikasi secara baik di dalam lingkungan sekolah, keluarga maupun masarakat. 


\section{Faktor-Faktor Yang Mempengaruhi Perkembangan Perilaku Asertif.}

Pembentukan tingkah laku asertifmulai pada awal kehidupan anak. Tingkah laku asertif merupakan hasil yang dicapai melalui proses interaksi dan berdasarkan pengalaman yang diterima anak. Pengalaman ini merupakan hasil interaksi anak terhadap lingkungannya. Terdapat 6 (enam) faktor yang mempengaruhi perkembangan perilaku asertif yaitu : 1) Jenis kelamin, wanita pada umumnya lebih sulit bersikap asertif dari pada laki-laki, 2) selfesteem, 3) kebudayaan, kebudayaan tuntunan lingkungan menentukan batas-batas perilaku, jenis kelamin, dan status sosial seseorang, 4) tingkat pendidikan, tingkat pendidikan tinggi semakin luas wawasan berfikir seseorang,5) tipe kepribadian, dalam situasi yang sama tidak semua individu memberikan respon yang sama, karena kepribadian seseorang yang berbeda dan 6) situasi tertentu lingkungan sekitarnya.Rahus dan Nevid (dalam http:zhalabe.blogspot.com.

Dari penjelasan tersebut di atas dapat disimpulkan, bahwasanya faktor yang mempengaruhi perkembangan perilaku asertif adalah : paling utamannya lingkungan tempat tinggal siswa itu sendiri, jenis kelamin dan tingkat pendidikan yang dimiliki oleh siswa.

\section{Konsep Perencanaan Karir}

Perencanaan karir adalah sesuatu yang menyangkut masa depan dalam jangka panjang yang harus direncanakan sejak jauh hari. Sunyoto (2015:165) mendifinisikan perencanaan karir (career planning) adalah proses yang dilalui oleh individu karyawan untuk mengidentifikasi dan mengambil langkah-langkah untuk mencapai tujuan karirnya. Frank Parson (dalam Winkel \& Hastuti (2010:408) merumuskan perencanaan karir yaitu suatu cara untuk membantu siswa dalam memilih suatu bidang karir yang sesuai dengan potensi mereka, sehingga dapat cukup berhasil di bidang pekerjaan. Perencanaan karir perlu disiapkan sebelum siswa terjun secara langsung dalam dunia karir.Perencanaan karir didasarkan atas potensi yang dimiliki siswa sehingga tidak ada pertentangan antara karir yang dipilih dengan potensi yang ada pada diri siswa.

Menurut pendapat ahli di atas, dapat disimpulkan bahwa perencanaan karir adalah : suatu proses dimana individu dapat mengidenfikasi dan mengambil langkah-langkah untuk mencapai tujuan karirnya. 


\section{Tujuan Perencanaan Karir}

Menurut Dillard (1985: 3-4), tujuan dari perencanaan karir adalah sebagai berikut: (a)Memperolah kesadaran dan pemahaman diri (acquiring self awernessand understanding).Dalam hal ini, kesadaran dan pemahaman diri merupakan penilaiandari kelebihan dankelemahanyangdimiliki individu.Langkah ini penting dalammemberikanpenilaianyangrealististentangdirinya sendiriuntukdipergunakandalamperencanaan karirnyaagar diperoleh arah yang efesien dalam kehidupan.(b) Mencapai kepuasan pribadi (attaraining personal satisfaction). Melaluikarir yang direncanakan terlebih dahulu, diharapkan individu tersebut akan mendapatkan kepuasaan pribadi dari karir yangditekuninya dalam kehidupannya.(c)Mempersiapkandiriuntuk memperolah penempatan danpenghasilan yang sesuai (preparingfor adequate placement).

\section{METODE PENELITIAN}

Penelitian ini merupakan suatu penelitian korelasi atau penelitian hubungan adalah penelitian yang dilakukan untuk mengetahui tingkat hubungan antara dua variabel yaitu variabel $\mathrm{x}$ (perilaku asertif) dan variabel y (perencanaan karir), tanpa melakukan perubahan atau manipulasi. Desain rancangan penelitiannya adalah sebagai berikut :
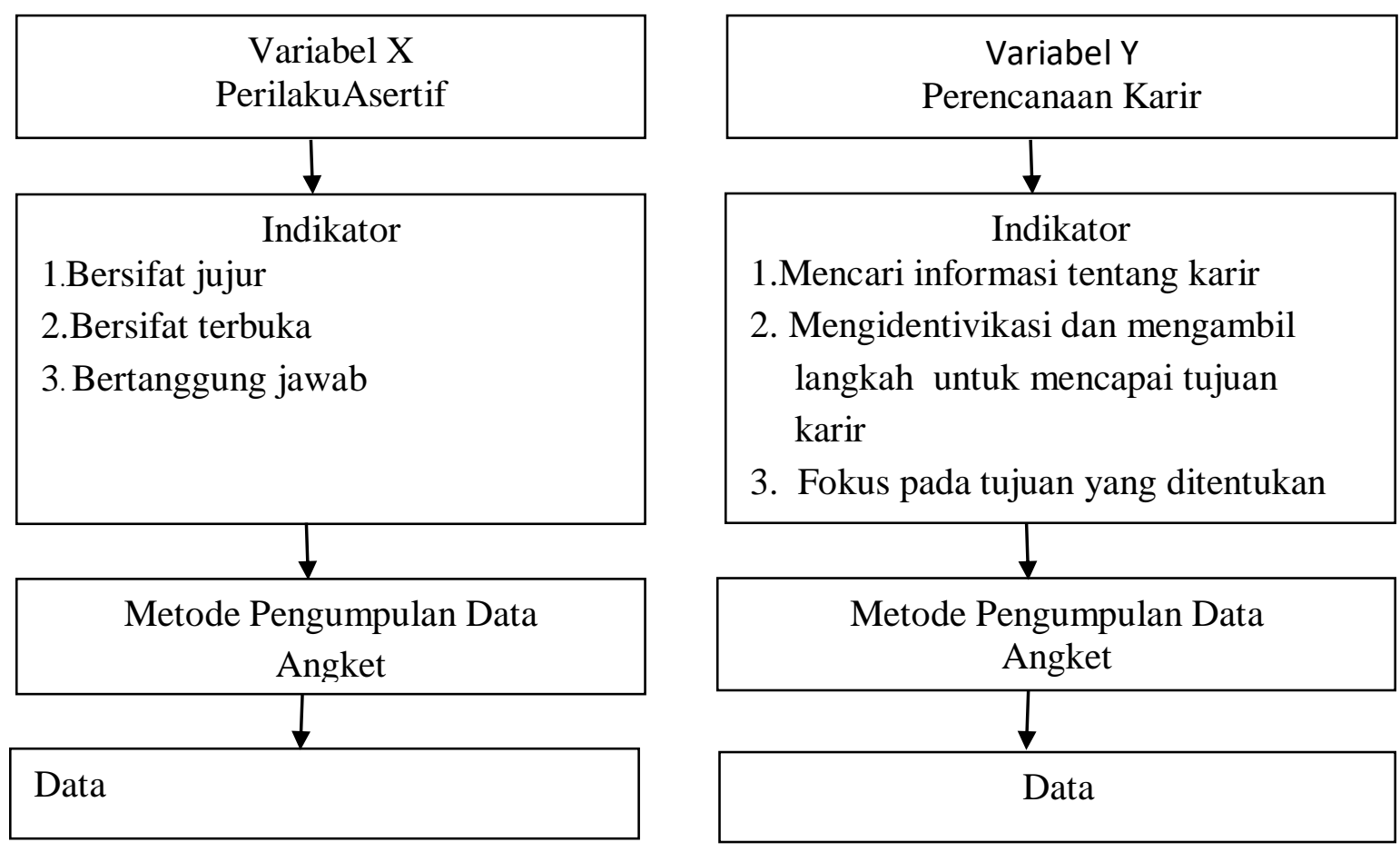


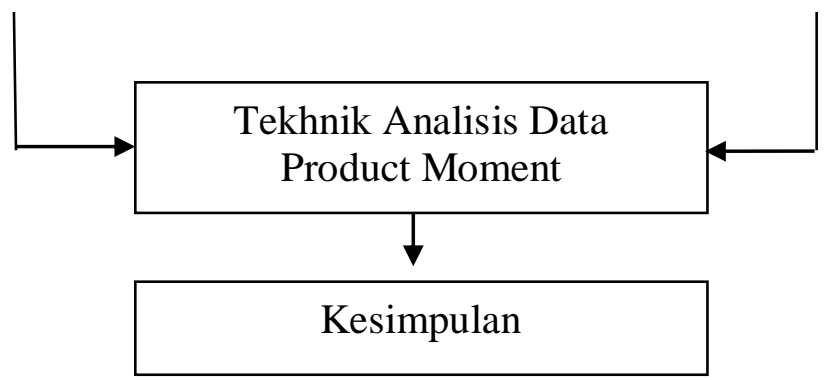

Gambar : 01 Rancangan Penelitian Korelasi Antara variabel X dan Variabel Y

Populasi dari penelitian ini adalah seluruh siswa MTs. NW Tanak Maik Masbagik Kabupaten Lombok Timur yang berjumlah 81 orang siswa, sedangkan sampel yang akan digunakan adalah sesuai dengan teknik penentuan sampel yakni apabila populasi lebih dari 100 maka populasi menggunakan proportinonal ramdom sampling dan jika jumlah populasi kurang dari 100 orang, maka lebih baik diambil semuanya, dan jika lebih dari 100 maka diambil 10\% - 15\% atau 20\% - 25\% atau tergantung dari kebutuhan dan kemampuan peneliti. (Suharsimi, 2009 : 134). Karena populasinya berjumlah 81 maka kemudian diambil semua, jadi merupakan penelitian populasi. Metode pengumpulan data adalah menggunakan angket sebagai metode pokok, sedangkan metode dokumentasi sebagai metode pelengkap.

\section{HASIL PENELITIAN}

Setelah dilakukan penelitian dan mengumpulkan data hasil penelitian tentang angket hubungan antara perilaku asertif dengan perencanaan karir Pada SiswaMTs. NW Tanak Maik Masbagik Kabupaten Lombok Timur, kemudian dilakukan analisis untuk mendapatkan hasil dan gambaran dari indikator penelitain. Berdasarkan hasil penyebaran angket hubungan antara perilaku asertif dengan perencanaan karir Pada SiswaMTs. NW Tanak Maik Masbagik Kabupaten Lombok Timur, dari hasil nilai data perilaku asertif sebesar sebesar 5855 dan hasil data angket perencanaan karir yaitu sebesar 5940. Untuk mempermudah hasil perhitungan dalam menguji hipotesis dapat dibuat tabel rekapitulasi.

Adapun langkah-langkah yang ditempuh dalam pengujian hipotesis ini sesuai dengan yang telah dicantumkan pada bab sebelumnya adalah sebagai berikut :

1) Merumuskan Hipotesis Nihil (Ho) 
Sehubungan dengan analisis data yang menggunakan analisis statistik, maka hipotesis alternative (Ha) yang diajukan yang berbunyi Ada Hubungan Antara perilaku asertif dengan perencanaan karir pada siswaMTs. NW Tanak Maik Masbagik Kabupaten Lombok Timur Maka perlu diubah terlebih dahulu kedalam sebuah hipotesis nol(Ho) sehingga berbunyi: Tidak ada Hubungan Antara perilaku asertif Dengan perencanaan karir Pada SiswaMTs. NW Tanak Maik Masbagik Kabupaten Lombok Timur.

2).Membuat Tabel Kerja.

Tabel kerja untuk pengolahan data yang telah dikumpulkan dengan metode angket dan dokumentasi guna menguji hipotesis tentang Hubungan Antara perilaku asertif dengan perencanaan karir pada siswaMTs. NW Tanak Maik Masbagik Kabupaten Lombok Timur.

Ket. $\sum x y=1.743,228$

$$
\begin{aligned}
& \sum x^{2}=2.673,683 \\
& \sum y^{2}=2.063,106
\end{aligned}
$$

3) Memasukkan Data Ke Dalam Rumus.

Berdasarkan data tabel di atas, maka data-data tersebut dimasukkan ke dalam rumus koefisien korelasi product moment ini :

$$
\begin{gathered}
r_{x y}=\frac{\sum x y}{\sqrt{\left(\sum x^{2}\right)\left(\sum y^{2}\right)}}=\frac{1743,228}{\sqrt{(2673,683)(2063,106)}}=\frac{1743.228}{\sqrt{5516091,439}}=\frac{1743.228}{2348,636} \\
=0,742
\end{gathered}
$$

4) Menguji Nilai Korelasi Product Moment

Berdasarkan hasil perhitungan di atas, ternyata Nilai $r_{x y}$ yang dihasilkan dengan rumus Product Moment dengan taraf "Signifikan" 5\% dengan N=81 dalam penelitian ini adalah sebesar 0,742 sedangkan $r_{\text {tabel }}=0,213\left(r_{\text {hitung }}>r_{\text {tabel }}\right)$ yaitu $(0,742>0,213)$ yang dinyatakan "Signifikan". Ini berarti hipotesis Alternatif (Ha) diterima, sedangkan Hipotesis Nihil (Ho) ditolak.

5) Menarik Kesimpulan Analisis 
Karena nilai $r$ hitung pada penelitian ini dinyatakan "Signifikan", dengan taraf "Signifikansi"5\% maka kesimpilan yang diperoleh dalam penelitian ini ada Hubungan Antara Perilaku Asertif dengan Perencanaan Karir Pada Siswa MTs. NW Tanak Maik Masbagik Kabupaten Lombok Timur”.

\section{PEMBAHASAN}

Berdasarkan pada hasil analisis di atas, dimana nilai $\mathrm{r}$ peoduct moment hasil penelitian setelah diperoleh nilai $r$ hitung dengan $\mathrm{N}=81$ dalam penelitian ini adalah sebesar $=0,742$, sedangkan $\mathrm{r}$ tabel dengan taraf signifikan $5 \%$ pada $\mathrm{N}=81$ harga tabel $=0,213$, ini menunjukkan bahwa nilai $\mathrm{r}$ tabel, atau ( $\mathrm{r}$ hitung $>\mathrm{r}$ tabel) yaitu $(0,742>0,213$, yang menyatakan bahwa hipotesis alternatif ( $\mathrm{Ha}$ ) yang diajukan diterima dan sebaliknya hipotesis nihil (Ho) yang diajukan ditolak yang artinya bahwa hasil penelitian ini adalah “signifikan". Dengan kata lainHal ini menunjukkan ini ada Hubungan Antara Perilaku Asertif dengan Perencanaan Karir Pada Siswa MTs. NW Tanak Maik Masbagik Kabupaten Lombik Timur bahwa nilai $r$ tabel, atau ( $\mathrm{r}$ hitung > r tabel) yaitu (0.417> 0.396 yang menyatakan bahwa hipotesis alternatif (Ha) yang diajukan diterima dan sebaliknya hipotesis nihil (Ho) yang diajukan ditolak yang artinya bahwa hasil penelitian ini adalah "signifikan".ini menunjukkan bahwa nilai $r$ tabel, atau ( $r$ hitung > r tabel) yaitu (0.417> 0.396 yang menyatakan bahwa hipotesis alternatif (Ha) yang diajukan diterima dan sebaliknya hipotesis nihil (Ho) yang diajukan ditolak yang artinya bahwa hasil penelitian ini adalah "signifikan".

Perilaku asertifadalah : satu bentuk tingkah laku interpersonal yang terdiri dari pada komunikasi secara lansung antar perorangan (interpersonal) yang melibatkan aspek kejujuran, keterbukaan pikiran dan perasaan terhadap diri sendiri dan orang lain, bisa berpikir rasoinal, berkeyakinan diri, mendengar pandangan orang lain memahami situasi orang lain, disamping memiliki sikap dan tanggung jawab. Sedangkan perencanaan karir adalah : suatu langkah yang dilakukan oleh siswa dalam menentukan arah pilihan karir sesuai dengan harapan agar siswa tidak salah dalam mengambil keputusan karir seperti kelanjutan studi, cita-cita serta pekerjaan yang diinginkan.

Perilaku asertif memiliki hubungan terhadap perencanaan karir pada siswa. Perilaku asertif merupakan indivudu yang mempunyai sifat terbuka, jujur dan bertanggung jawab yang bisa memgekspresikan dalam lingkungan sosial dan bisa 
merencanakan yang diinginkan untuk mencapai tujuan tertentu. Siswa yang memiliki perilaku asertif dapat mengenal dirinya dan bisa meningkatkan perancanaan karir sesuai kemampuan yang dimiliki agar tercapai semua tujuan yang diinginkan.

Dengan demikian peneliti menyimpulkan, bahwa perilaku asertif mempunyai hubungan dengan perencanaan karir Pada Siswa MTs. NW Tanak Maik Masbagik Kabupaten Lombik Timur, karena nilai $r$ hitung lebih besar dari pada $r$ tabel ( $r$ hitung > r tabel) yang berarti bahwa penelitian ini "signifikan".

\section{SIMPULAN}

Setelah dilaksanakan analisis data diperoleh hasil penelitian atau $\mathrm{r}$ hitung $\mathrm{N}=81$ dalam penelitian ini adalah sebesar $=0.742$, sedangkan $r$ tabel dengan taraf signifikan $5 \%$ pada $\mathrm{N}=81$ menunjukkan harga $\mathrm{r}$ tabel $=0.213$ ini menunjukkan bahwa nilai $\mathrm{r}$ tabel, atau ( $\mathrm{r}$ hitung $>\mathrm{r}$ tabel) yaitu $(0.742>0.213)$ hipotesis alternatif (Ha) diterima sedangkan hipotesis nihil (Ho) ditolak. Yang berarti hasil penelitian ini adalah "signifikan", dengan demikian dapat ditarik kesimpulan bahwa Ada hubungan antara perilaku asertif dengan perencanaan karir pada siswa MTs. NW Tanak Maik Masbagik Kabupaten Lombok Timur, artinya siswa yang memiliki perilaku asertif dengan perencanaan karir memiliki hubungan signifikan dengan lingkungan di sekolah. Jadi kesimpulanya adalah sebagai berikut: Ada hubungan antara perilaku asertif dengan perencanaan karir pada siswa MTs. NW Tanak Maik Masbagik Kabupaten Lombok Timur.

Berdasarkan simpulan di atas, maka disaran untuk kepala sekolah, sekolah diharapkan hasil penelitian dapat memberikan kontribusi dalam mengembangkan perilaku asertif siswa dengan merencanakan kari dalam mempersiapkan dunia kerja. Kepada para guru, dapat memberikan peroses pemebelajaran yang dapat membentuk sikap asertif siswa yang baik dalam menunjang kinerrja mereka sebagai pengajar professional dalam mengembangkan perenanaan karir yang baik. Kepada para siswa diharapkan mampu mengembangkan dan membentuk sikaf asertif yang baik agar apa yang diharapkan mampu dicapai terutama dalam mengembangkan perencanaan karir dalam dunia kerja. Para peneliti lain, dapat mengembangkan hasil penelitian yang baik 
dan berguna bagi orang lain terutama siswa dalam peroses pengembangan perilaku asertif mereka yang baik.

\section{DAFTAR PUSTAKA}

Arikunto, Suharsimi. (2009). Prosedur Penelitian, Suatu Pendekatan Praktek. Jakarta: Rineka.

Adiputra, Sofwan. 2015. "Penggunaan Teknik Modeling Terhadap Perencanaan Karir Siswa". Jurnal Fokus Konseling, (Online), Vol 1, No. 1. (https://core.ac.uk/download/pdf/229583727.pdf).

Dillard. J. M. (1985), Lifelong Career Planing. Ohio: A bell \& Howell Company Colombus

Falmer, Froknor, "http:zhalabe.blogspot.comdiaksese hari kamis 17 Desember 2015, pukul 19:30 WITA

Gunarsa, Singgih D. 2009. Konseling dan Psikotrapi. Jakarta : Gunung mulia.

Khan, Rosa,Imani.2012. Perilaku Asertif, Harga Diri dan Kecenderungan Depresi, Jurnal Psikologi Indonesia.

Sofwan Adiputra, "Penggunaan Teknik Modeling terhadap Perencaan Karir Siswa", Jurnal Fokus Konseling, Volume 1 No. 1, Januari 2015.45-46.

Sugiyono. 2010. Metode Penelitian Kuntitatif Kualitatif dan $R \& D$. Bandung: Alfabeta.

Suyonto, Danang. 2015. Manajemen dan Pengembangan Sumber Daya Manusia. CAPS (Center for Academic Publishing Service), Yogyakarta.

Winkel, W. S \& Hastuti, S. (2010). Bimbingan dan Konseling di Institusi Pendidikan. Yogyakarta: Media Abadi.

Walgito, Bimo,2010. Bimbingan dan Konseling (Studi \&Karir).Yogyakarta: Andi. 